\section{Dose-Response and Time-Course of $\alpha$-Tocoferol Mediating the Cytoprotection of Dental Pulp Cells Against Hydrogen Peroxide}

Fernanda da Silveira Vargas ${ }^{1}$, Diana Gabriela Soares ${ }^{2}$, Fernanda Gonçalves Basso $^{3}$, Josimeri Hebling ${ }^{3}$, Carlos Alberto de Souza Costa ${ }^{2}$

This in vitro study evaluated the potential protective effect of vitamin $\mathrm{E}$ alpha-tocopherol $(\alpha-T)$ isomer against the toxicity of hydrogen peroxide (HP) applied on dental pulp cells. Odontoblast-like MDPC-23 cells were seeded on 96-well plates for $72 \mathrm{~h}$, treated with different concentrations of $\alpha-T(1,3,5$, and $10 \mathrm{mM})$ for different times $(1,4,8$, and 24 h) and then exposed or not to a $0.018 \% \mathrm{HP}$ solution for $30 \mathrm{~min}$. In positive and negative control groups, cells were exposed to HP or culture medium (DMEM containing 5\% DMSO), respectively. Cell viability was assessed by the MTT assay and the absorbance numeric data, expressed as percentage values, were subjected to the statistical analysis by KruskalWallis and Mann-Whitney tests $(\alpha=5 \%)$. Considering the cells in the negative control as having $100 \%$ of cell viability, all combinations of $\alpha$-T concentrations and pretreatment times showed a protective effect against HP cytotoxicity. Significant reduction of cell viability (59\%) was observed in the positive control compared with the negative control. The highest values of pulp cell viability were obtained after pretreatment with 1 and $3 \mathrm{mM} \alpha-\mathrm{T}$ concentrations for $24 \mathrm{~h}$ followed by exposure to HP $(126 \%$ and $97 \%$ of cell viability, respectively). Under the tested conditions, the most effective cell protection against the cytotoxic effects of HP was provided by the lowest concentrations of $\alpha-\mathrm{T}$ (1 and $3 \mathrm{mM}$ ) applied for $24 \mathrm{~h}$.
'Department of Dental Materials and Prosthodontics, Univ Estadual Paulista - UNESP, Araraquara School of Dentistry, Araraquara, SP, Brazil ${ }^{2}$ Department of Physiology and Pathology, Univ Estadual Paulista - UNESP, Araraquara School of Dentistry, Araraquara, SP, Brazil ${ }^{3}$ Department of Orthodontics and Pediatric Dentistry, Univ Estadual Paulista - UNESP, Araraquara School of Dentistry, Araraquara, SP, Brazil

Correspondence: Prof. Dr. Carlos Alberto de Souza Costa, Rua Humaitá, 1680. Centro, Caixa Postal 331, 14801903 Araraquara, SP, Brasil. Tel: + 55-16-3301-6477. e-mail: casouzac@foar.unesp.br

Key Words: hydrogen peroxide, odontoblasts, tooth bleaching, vitamin $\mathrm{E}$.

\section{Introduction}

Hydrogen peroxide (HP) is a molecule with a well-known oxidant intracellular activity during the biologic process of cellular respiration. HP and other reactive oxygen species (ROS) resulting from its degradation are highly reactive and unstable, and have a rapid interaction with cellular macromolecules such as proteins, lipids and nucleic acids. Antioxidant enzymes act inactivating ROS in order to maintain balance and permit an adequate functioning of the cell (1).

High concentrations (30-40\%) of HP have been widely used in esthetic dentistry to treat discolored teeth because of its capacity to oxidize the complex organic molecules of the dental structure that respond for darkening of teeth. Clinically, the use of these bleaching gels has been shown to cause postoperative tooth sensitivity (2) and side effects on dental pulp tissue, ranging from acute inflammatory response to the formation of areas of necrosis $(3,4)$, as a result of HP diffusion through the dentinal tubules, reaching the pulp chamber (5) and causing an oxidative stress to pulp cells (6). In view of this, it has been suggested that the application of antioxidant agents prior to bleaching procedures could prevent extracellular and intracellular oxidative damages caused to the pulp cells by HP leached from bleaching gel components $(7,8)$. Among the available options, vitamins have aroused interest because they participate in immune response regulation, acting as both antiinflammatory and antioxidant agents (9). Vitamin $E(V E)$, which is involved in the prevention of oxidative events is a blend of tocopherols and tocotrienols, both presenting four isomers $(\alpha, \beta, \gamma$ and $\delta$ ) (10). Nevertheless, it is known that the antioxidant action of VE is mediated by its alpha-tocopherol $(\alpha-T)$ isomer, which has the capacity to incorporate to the cell membrane and stop lipid peroxidation propagation (11). Several researchers have assessed the protective effect of $\alpha$-T and confirmed its capacity to prevent oxidative stress propagation, stabilize the cell membrane, enhance cell viability and increase the amount of endogenous antioxidants (12-17).

In dental research, Majd et al. (18) verified that treating human gingival fibroblasts with the water-soluble $\alpha-T$ isomer reduced significantly the oxidative stress generated by resinous dental materials. In a recent study, Vargas et al. (8) demonstrated that high $\alpha$-T concentrations presented a protective action on odontoblast-like cells exposed to HP after a short pretreatment time, but the toxic effect was still observed. Based on the above considerations and due to the scarcity of studies combining pulp cells, antioxidant agents and bleaching gels, it was hypothesized that the antioxidant action of $V E$, specifically its $\alpha-T$ isomer, could 
protect the pulp cells against the toxicity of HP, the main component of bleaching products. Therefore, the aim of this study was to evaluate and determine the effective pretreatment time and $\alpha-T$ concentration to protect dental pulp cells against HP aggression.

\section{Material and Methods}

\section{Cell Culture}

Odontoblast-like MDPC-23 cells were seeded in serumfree Dulbecco's Modified Eagle's Medium (DMEM; Sigma Aldrich Corp., St. Louis, MO, USA) supplemented with 10\% fetal bovine serum (FBS; Gibco Co., Grand Island, NY, USA) with $100 \mathrm{IU} / \mathrm{mL}$ penicillin, $100 \mu \mathrm{g} / \mathrm{mL}$ streptomycin and 2 $\mathrm{mmol} / \mathrm{L}$ glutamine (Gibco) in an humidified incubator with $5 \% \mathrm{CO}_{2}$ and $95 \%$ air at $37{ }^{\circ} \mathrm{C}$ (Isotemp Fisher Scientific, Pittsburgh, PA, USA). The MDPC-23 cells were sub-cultured every 3 days until an adequate number of cells were obtained for the study.

\section{Evaluation of $\alpha$-TProtective Effect Against HPToxicity}

In order to evaluate the protective effect of $\alpha$-T against HP toxicity, solutions containing four $\alpha-T$ concentrations were prepared by diluting a stock $\alpha$-T solution (Sigma $\dot{\vec{s}}$ Chemical Co.) in DMEM with 5\% dimethyl sulfoxide (DMSO) (18). Experimental groups to assess the protective role of $\alpha-T$ against cell toxicity mediated by HP were formed according to the combination of $\alpha$-T concentrations $(1,3$, 5 , and $10 \mathrm{mM})$ and pretreatment times $(1,4,8$ and $24 \mathrm{~h})$. After the pretreatment with $\alpha-T$, the MDPC-23 cells were exposed or not to a $0.018 \% \mathrm{HP}$ solution for $30 \mathrm{~min}$. This HP concentration has been proven to reduce cell viability by approximately $50 \%$ (IC-50) (8) and was prepared by diluting a stock 35\% HP solution (Whiteness HP, FGM, Joinville, SC, Brazil) in serum-free DMEM immediately before application on the cells. In the negative and positive control groups, DMEM containing 5\% DMSO and $0.018 \% \mathrm{HP}$ were applied on the cells for $30 \mathrm{~min}$, respectively.

After bleaching treatments, the MTT assay was performed to evaluate cell viability by a cytochemical demonstration of the succinic dehydrogenase enzyme (SDH) (19). The solutions were aspirated and replaced by a solution containing $90 \mu \mathrm{LDMEM}$ and $10 \mu \mathrm{L}$ of MT solution (Sigma Chemical Co.) at a $5 \mathrm{mg} / \mathrm{mL}$ PBS concentration. The cells remained in this solution for $4 \mathrm{~h}$ in a humidified incubator containing $5 \% \mathrm{CO}_{2}$ and $95 \%$ air at $37{ }^{\circ} \mathrm{C}$. After $4 \mathrm{~h}$, the culture medium with MTT solution was aspirated and replaced by $100 \mu \mathrm{L}$ of an acidified isopropanol solution $(\mathrm{HCl} 0.04 \mathrm{~N})$ to dissolve the formazan crystals resulting from the MTT ring cleavage by the SDH enzyme in the viable cells mitochondria. Spectrophotometry assessed the cell viability as being proportional to the absorbance measured at $570 \mathrm{~nm}$ in an ELISA reader (Thermo Plate, Shenzhen,
Gandong, China). The obtained values were expressed as percentage of the cells exposed to culture medium (mean absorbance of negative control $=100 \%$ viability). Three independent experiments were performed at different times to demonstrate the reproducibility of data, and, in each appointment, six replicates $(n=6)$ were used for each group.

\section{Statistical Analysis}

The Kolmogorov-Smirnov $(n>50)$ test was applied to evaluate data distribution. Since the cell viability data did not adhere to the normality curve, non-parametric tests were applied. Kruskal-Wallis test followed by the Mann-Whitney were used. Significance level was set at $5 \%$ with the null hypotheses that HP does not produce toxic effects on odontoblast-like cells and that $\alpha-T$ is not capable of eliminating or decreasing the oxidative effects of the bleaching agent.

\section{Results}

Cell viability data obtained after cell pretreatment with $\alpha$-T followed or not by exposure to HP are shown in Table 1. For the 1-h pretreatment time, $\alpha-T$ efficacy was proportional to the concentration, i.e., the higher the concentration, the greater the protective effect. No statistically significant difference $(p>0.05)$ was found between 3 and $5 \mathrm{mM}$ concentrations, while the highest cell viability values were obtained for the $10 \mathrm{mM}$ concentration $(p<0.05)$. For the $4-h$ and $8-h$ pretreatment times, the 3,5 and $10 \mathrm{mM}$ concentrations presented a statistically similar protective effect $(p>0.05)$, but all of them differed significantly $(p<0.05)$ from the positive control (HP). When the cells were pretreated with $\alpha$-T for $24 h$, it was observed that the lower its concentration, the greater its protective effect. Considering the negative control group as having $100 \%$ of cell viability, the 1 and $3 \mathrm{mM}$ concentrations produced the highest values of metabolic activity at this pretreatment time, with no statistically significant difference ( $p>0.05$ ) between them.

According to the results, both null hypotheses were rejected.

\section{Discussion}

There is a consensus on vital tooth bleaching research that HP and its byproducts released from bleaching agents may diffuse through the mineralized dental tissues and reach the pulp space $(3,4)$. In contact with the pulp cells, $\mathrm{HP}$ and the ROS resulting from its degradation produce a direct oxidative damage and may generate a secondary oxidative stress due to the imbalance between the amount of ROS and intracellular antioxidants (1). The present study evaluated the protective action of VE $\alpha-T$ isomer at different concentrations $(1,3,5$ and $10 \mathrm{mM})$ used for 
various pretreatment times $(1,4,8$ and $24 \mathrm{~h})$ against the toxicity of HP applied on MDPC-23 odontoblast-like cells.

This specific kind of pulp cell, which have odontoblast phenotype, was used because odontoblasts are organized in a monolayer that underlies the coronal and root dentin of mammalian teeth (20). Therefore, any chemical agent that is capable to diffuse through the enamel and dentinal tubules will interact first with these highly specialized peripheral pulp cells (21). Odontoblasts are considered as the first defense line of the pulp-dentin complex because of their direct participation in pulp's immune and inflammatory response (22). In addition, they have a key role in maintaining the homeostasis of the pulp-dentin complex by producing dentin both physiologically and as a response to aggressive stimuli $(21,22)$. Therefore, clinical procedures on vital teeth should be effective without being harmful to pulp cells (22). The toxicity of HP from bleaching agents on cultured MDPC-23 odontoblast-like cells has been extensively demonstrated. A 50-60\% decrease in cell viability has been show to occur when the toxic components from the trans-enamel and trans-dentinal diffusion of bleaching gels with high HP concentration (35\%) were applied for $1 \mathrm{~h}$ on these cells (23). Therefore, the present study evaluated the protective effect of $\alpha-T$ applied on MDPC-23 cell cultures before exposure to a HP concentration (0.018\%) known to cause almost 50\% decrease in cell viability in the MTT assay (8).

In this study, all $\alpha$-T tested concentrations produced a decrease of HP-mediated aggression to the cells. The longer the contact of cells with $\alpha-T$, the lower the concentration necessary to obtain an effective cell protection. The opposite was also true, since shorter contact times required higher $\alpha-T$ concentrations to provide cell protection. When 1 , 4 and $8 \mathrm{~h}$ pretreatment times were used, there was a significant increase in cell viability when the cells were pretreated with 3, 5 and $10 \mathrm{mM}$ concentrations before exposure to HP, which presented similar behavior. However, when the cells were pretreated for $24 \mathrm{~h}$, the 1 and $3 \mathrm{mM}$ concentrations produced the highest cell viability of all combinations, $97 \%$ and $126 \%$, respectively, considering the negative control group (culture medium) as having 100\% of cell viability. Cells exposed to HP only, presented only $41 \%$ of cell viability. The capacity of $\alpha-T$ to incorporate to cell membrane has been shown to enhance cell functional balance, reducing membrane permeability by interacting with its polyunsaturated fat acids and discontinuing lipid peroxidation propagation $(10,12)$. This VE isomer can donate one of its electrons to free radicals, thus stabilizing these radicals and stopping oxidative stress propagation. Previous studies have demonstrated $\alpha$-T efficacy against HP-induced oxidative stress on different cell types, such as astrocytes, placental cells, fibroblasts and hepatocytes

Table 1. Percentage of viability of MDPC-23 cells treated with different alpha-tocopherol $(\alpha-T)$ concentrations followed by exposure or not to $0.018 \%$ hydrogen peroxide (HP)

\begin{tabular}{|c|c|c|c|c|c|c|}
\hline \multirow{2}{*}{$\begin{array}{l}\alpha-T \\
\text { pretreatment } \\
\text { time }\end{array}$} & \multirow{2}{*}{$\begin{array}{l}\text { HP exposure } \\
\text { (30 min) }\end{array}$} & \multicolumn{5}{|c|}{$\alpha-\mathrm{T}$ concentration } \\
\hline & & None & $1 \mathrm{mM}$ & $3 \mathrm{mM}$ & $5 \mathrm{mM}$ & $10 \mathrm{mM}$ \\
\hline \multirow{3}{*}{$1 \mathrm{~h}$} & No & $103(100-103)^{* a}$ & $92(89-95)^{a b}$ & $92(86-94)^{a b}$ & $91(88-93)^{a b}$ & $84(77-95)^{b}$ \\
\hline & Yes & $34(32-41)^{c}$ & $50(48-54)^{\mathrm{bc}}$ & $62(58-70)^{\mathrm{ab}}$ & $65(63-67)^{\mathrm{ab}}$ & $82(74-97)^{a}$ \\
\hline & Sig. ${ }^{* *}$ & $<0.001$ & $<0.001$ & $<0.001$ & $<0.001$ & 0.603 \\
\hline \multirow{3}{*}{$4 \mathrm{~h}$} & No & $100(93-105)^{a}$ & $95(93-99)^{a b}$ & $85(83-89)^{b c}$ & $88(84-90)^{b c}$ & $74(65-86)^{c}$ \\
\hline & Yes & $36(33-45)^{b}$ & $53(48-55)^{b}$ & $80(65-101)^{a}$ & $74(67-88)^{\mathrm{a}}$ & $77(70-82)^{\mathrm{a}}$ \\
\hline & Sig.** & $<0.001$ & $<0.001$ & 1.000 & 0.065 & 0.525 \\
\hline \multirow{3}{*}{$8 \mathrm{~h}$} & No & $100(97-104)^{\mathrm{a}}$ & $96(92-102)^{a b}$ & $84(80-91)^{\mathrm{b}}$ & $93(85-103)^{\mathrm{ab}}$ & $88(74-97)^{\mathrm{ab}}$ \\
\hline & Yes & $37(33-43)^{\mathrm{b}}$ & $55(50-65)^{a}$ & $64(57-76)^{\mathrm{a}}$ & $64(54-75)^{a}$ & $73(65-79)^{\mathrm{a}}$ \\
\hline & Sig."* & $<0.001$ & $<0.001$ & $<0.001$ & $<0.001$ & 0.028 \\
\hline \multirow{3}{*}{$24 \mathrm{~h}$} & No & $100(97-105)^{a}$ & $84(83-86)^{b c}$ & $112(107-115)^{\mathrm{a}}$ & $97(92-102)^{a b}$ & $76(59-82)^{c}$ \\
\hline & Yes & $41(37-47)^{b}$ & $126(115-131)^{\mathrm{a}}$ & $97(95-108)^{a}$ & $67(58-70)^{\mathrm{b}}$ & $46(43-51)^{\mathrm{b}}$ \\
\hline & Sig."* & $<0.001$ & 0.005 & 0.018 & $<0.001$ & $<0.001$ \\
\hline
\end{tabular}

* values of percentage of viability of MDPC-23 cells are expressed as medians (25 percentile -75 percentile), $n=18 .{ }^{* *} p$ value (Mann-Whitney) that allows comparison between exposure or not to hydrogen peroxide for the same alpha-tocopherol concentration and pretreatment time. ${ }^{\text {a }}$ same letters can be compared in rows; medians with the same letter have no statistically significant difference (Mann-Whitney test, $p>0.05$ ). 
$(13,14)$. Additionally, $\alpha-T$ increases the expression of endogenous antioxidants, such as dismutase superoxide and catalase (15-17), and reduces gene expression of inflammatory mediators (9). In this way, $\alpha-T$ has an effective role in antioxidant and antiinflammatory events (24). Previous studies demonstrated that this VE isomer is able to incorporate to the membranes of specific cell types within 24 to $27 \mathrm{~h}$ (25). In view of this and considering the functions and proprieties of $\alpha-T$, it is possible to speculate that the positive results obtained after pretreatment of cells with 1 and $3 \mathrm{mM}$ concentrations of this isomer for $24 \mathrm{~h}$, might have occurred because the time was sufficient for incorporation of this antioxidant agent to cell membrane. As far as tooth bleaching is concerned, $\alpha$-T incorporation to cell membrane could prevent the lipid peroxidation caused by the ROS. It could be speculated that the protective action for the 24-h pretreatment time occurred due to $\alpha$-T incorporating to cell membrane; for shorter treatment times $(1,4$ and $8 \mathrm{~h}$ ) the protective effect was possibly due to a concentration-dependent extracellular action.

Although laboratory-based results cannot be directly extrapolated to clinical situation, the original data obtained under the tested experimental conditions demonstrated $\overrightarrow{\vec{s}}$ that $\alpha$-T was capable of protecting MDPC-23 pulp cells against the harmful effects of HP, suggesting that the application of this VE isomer before bleaching procedures might have an important role in minimizing oxidative damage to the pulp cells. Apart from its protective effect against oxidizing agents, $\alpha$-T has a broad therapeutic potential, which includes an antiinflammatory action that may avoid post-bleaching tooth sensitivity, a frequent adverse effect of vital bleaching procedures. Further in vivo studies are required, especially those evaluating the relationship among tooth bleaching, postoperative sensitivity and antioxidant agents, to corroborate the potential protective effects of specific $\alpha$-T concentrations on the pulp tissue. According to the methodology used in this research, it was possible to conclude that VE $\alpha$-T isomer has a protective effect on the MDPC-23 odontoblast-like cells against the toxicity of HP. The most effective cell protection was provided by the lowest concentrations of $\alpha-\mathrm{T}$ ( 1 and $3 \mathrm{mM}$ ) with pretreatment time of $24 \mathrm{~h}$.

\section{Acknowledgements}

The authors acknowledge the Fundação de Amparo à Pesquisa do Estado de São Paulo - FAPESP (grant \# 2013/23520-0), Conselho Nacional de Desenvolvimento Científico e Tecnológico - CNPq (grant \# 301029/2010-1), and FUNDUNESP (grant \# 0024/021/13-PROPE-CDC) for financial support.

\section{Resumo}

Neste estudo, foi avaliado o potencial protetor do isômero alfa-tocoferol da vitamina $E(\alpha-T)$ contra a ação tóxica do peróxido de hidrogênio (PH) aplicado sobre células pulpares. Células odontoblastóides MDPC-23 foram semeadas em placas de 96 compartimentos por $72 \mathrm{~h}$, tratadas com diferentes concentrações de $\alpha-T(1,3,5$ e $10 \mathrm{mM})$ por diferentes períodos (1, 4, 8 e 24 h) e, então, expostas ou não a uma solução com $0,0018 \%$ de $\mathrm{PH}$ por $30 \mathrm{~min}$. Nos controles positivo e negativo, as células foram expostas ao PH ou meio de cultura (DMEM contendo 5\% de DMSO), respectivamente. A viabilidade celular foi avaliada pelo teste do MT e os valores numéricos de absorbância, expressos em porcentagem, foram submetidos a análise estatistica pelos testes de Kruskal-Wallis e MannWhitney $(\alpha=5 \%)$. Considerando as células do grupo controle negativo como apresentando $100 \%$ de viabilidade celular, todas as combinações de $\alpha-T$, nas diferentes concentrações, e tempos de pré-tratamento demonstraram um efeito protetor contra a citotoxicidade do PH. Redução significativa da viabilidade (59\%) foi observada para o grupo controle positivo comparado ao controle negativo. Os maiores valores de viabilidade celular foram obtidos após pré-tratamento com 1 e $3 \mathrm{mM}$ de $\alpha$-T por 24 h seguido de exposição ao PH (126\% e 97\% de viabilidade celular, respectivamente). Assim, de acordo com as condições experimentais, o efeito protetor mais efetivo contra os efeitos tóxicos do $\mathrm{PH}$ foi observado para as menores concentrações de $\alpha-\mathrm{T}$ (1 e $3 \mathrm{mM}$ ) aplicado por $24 \mathrm{~h}$.

\section{References}

1. Cecarini V, Gee J, Fioretti E, Amici M, Angeletti M, Eleuteri AM, et al. Protein oxidation and cellular homeostasis: emphasis on metabolism. Biochim Biophys Acta 2007;1773:93-104.

2. Reis A, Tay LY, Herrera DR, Kossatz S, Loguercio AD. Clinical effects of prolonged application time of an in-office bleaching gel. Oper Dent 2011;36:590-596.

3. de Souza Costa CA, Riehl H, Kina JF, Sacono NT, Hebling J. Human pulp responses to in-office tooth bleaching. Oral Surg Oral Med Oral Pathol Oral Radiol Endod 2010;109:59-64.

4. Cintra LT, Benetti F, da Silva Facundo AC, Ferreira LL, Gomes-Filho JE, Ervolino $E_{\text {, et }}$ al. The number of bleaching sessions influences pulp tissue damage in rat teeth. J Endod 2013:39:1576-1580.

5. Camargo SE, Valera MC, Camargo CH, Gasparoto Mancini MN, Menezes MM. Penetration of $38 \%$ hydrogen peroxide into the pulp chamber in bovine and human teeth submitted to office bleach technique. J Endod 2007;33:1074-1077.

6. Soares DG, Basso FG, Hebling J, de Souza Costa CA. Concentrations of and application protocols for hydrogen peroxide bleaching gels: effects on pulp cell viability and whitening efficacy. J Dent 2014;42:185-198.

7. Lima AF, Lessa FC, Hebling J, de Souza Costa CA, Marchi GM. Protective effect of sodium ascorbate on MDPC-23 odontoblast-like cells exposed to a bleaching agent. Eur J Dent 2010;4:238-244.

8. da Silveira Vargas F, Soares DG, Ribeiro AP, Hebling J, De Souza Costa CA. Protective effect of alpha-tocopherol isomer from vitamin $E$ against the $\mathrm{H} 2 \mathrm{O} 2$ induced toxicity on dental pulp cells. Biomed Res Int 2014 [Epub ahead of print. DOI: 10.1155/2014/895049].

9. Wintergerst ES, Maggini S, Hornig DH. Contribution of selected vitamins and trace elements to immune function. Ann Nutr Metab 2007;51:301-323.

10. Aggarwal BB, Sundaram C, Prasad S, Kannappan R. Tocotrienols, the vitamin $\mathrm{E}$ of the 21st century: its potencial against cancer and other chronic diseases. Biochem Pharmacol 2010;80:1613-1631.

11. Upadhyay J, Misra K. Towards the interaction mechanism of tocopherols and tocotrienols (vitamin E) with selected metabolizing enzymes. Bioinformation 2009;3:326-331.

12. Azzi A. Molecular mechanism of alpha-tocopherol action. Free Radic Biol Med 2007;43:16-21.

13. Makpol S, Zainuddin A, Rahim NA, Yusof YA, Ngah WZ. Alphatocopherol modulates hydrogen peroxide-induced DNA damage and telomerase shortening of human skin fibroblasts derived from differently aged individuals. Planta Med 2010;76:869-875.

14. Yurdakul T, Kulaksizoglu H, Piskin MM, Avunduk MC, Ertemli E, Gokçe $\mathrm{G}$, et al.. Combination antioxidant effect of $\alpha$-tocopherol and erdosteine in ischemia-reperfusion injury in rat model. Int Urol Nephrol 2010;42:647-655. 
15. Guney M, Erdemoglu E, Mungan T. Selenium-vitamin E combination and melatonin modulates diabetes-induced blood oxidative damage and fetal outcomes in pregnant rats. Biol Trace Elem Res 2011;143:1091-1102.

16. Tahan G, Aytac E, Aytekin H, Gunduz F, Dogusoy G, Aydin S, et al.. Vitamin $E$ has dual effect of anti-inflammatory and antioxidant activities in acetic acid-induced ulcerative colitis in rats. Can J Surg 2011;54:333-338.

17. Yilmaz N, Yilmaz M, Altuntas I. Diozinon-induced brain toxicity and protection by vitamins E plus C. Toxicol Ind Health 2012:28:51-57.

18. Majd ES, Goldberg M, Stanislawski L. In vitro effects of ascorbate and Trolox on the biocompatibility of dental restorative materials. Biomaterials 2003;24:3-9.

19. Soares DG, Ribeiro AP, Lima AF, Sacono NT, Hebling J, Souza Costa CA. Effect of fluoride-treated enamel on indirect cytotoxicity of a $16 \%$ carbamide peroxide bleaching gel to pulp cells. Braz Dent J 2013;24:121-127.

20. Couve $E_{1}$ Schmachtenberg 0 . Response to letter to the editor, "the amazing odontoblast: activity, autophagy, and aging": why rename the amazing odontoblast? J Dent Res 2013;92:1143.
21. Souza Costa CA, Hebling J, Scheffel DL, Soares DG, Basso FG, Ribeiro AP. Methods to evaluate and strategies to improve the biocompatibility of dental materials and operative techniques. Dent Mater 2014;30:769784.

22. Cooper PR, Takahashi $Y$, Graham LW, Simon S, Imazato S, Smith AJ. Inflammation-regeneration interplay in the dentine-pulp complex. J Dent 2010;38:687-697.

23. Soares DG, Ribeiro AP, Silveira Vargas F, Hebling J, Souza Costa CA. Efficacy and cytotoxicity of a bleaching gel after short application times on dental enamel. Clin Oral Investig 2013;17:1901-1909.

24. Atkinson J, Epand RF, Epand RM. Tocopherols and tocotrienols in membranes: a critical review. Free Radic Biol Med 2008:44:739-764.

25. Saito Y, Yoshida Y, Akazawa T, Takahashi K, Niki E. Cell death caused by selenium deficiency and protective effect of antioxidants. J Biol Chem 2003;278:39428-39434.

Received March 25, 2014 Accepted September 232014 